\title{
Pengusulan HKI (Hak Kekayaan Intelektual) untuk Petunjuk Praktikum Bioteknologi Berbasis Guided Inquiry
}

\author{
Sahratullah $^{1}$, Ari Ashari ${ }^{2}$ \\ ${ }^{12}$ Dosen Program Studi Pendidikan Biologi, FKIP, Universitas Cordova \\ Email: sahratullah11@gmail.com
}

\begin{abstract}
Abstrak
Penelitian ini bertujuan untuk melakukan penerapan pengembangan petunjuk praktikum berbasis guided inquiry untuk meningkatkan kemampuan berpikir kritis peserta didik SMA. Penelitian pengembangan ini menggunakan model 4D dengan tahapan Pendefinisian (Define), Perancangan (Design), Pengembangan (Develop), Penyebaran (Disseminate). Sebelum dilakukan tahapan penyebaran, perlu dilakukan pengusulan HKI (Hak Kekayaan Intelektual) terhadap Petunjuk Praktikum Bioteknologi Berbasis Guided Inquiry. Proses pengusulan sudah dilakukan dari bulan Januari Tahun 2021 dan terbit pada bulan April 2021. Sertifikat HKI yang berhasil diperoleh untuk Buku Petunjuk Praktikum Bioteknologi Berbasis Guided Inquiry sebagai Pegangan Guru SMA dan Buku Petunjuk Praktikum Bioteknologi Berbasis Guided Inquiry untuk Peserta Didik SMA Kelas XII Semester 2. Dengan adanya sertifikat HKI diharapkan dapat meningkatkan reputasi dan citra peneliti dan sivitas akademika suatu universitas di tingkat nasional maupun internasional.
\end{abstract}

Kata kunci: HKI, Petunjuk Praktikum, Guided Inquiry

\section{PENDAHULUAN}

Proses pembelajaran peserta didik secara aktif dalam mengembangkan potensi dirinya dalam suatu usaha sadar dan terencana merupakan pengertian dari pendidikan (Peraturan Pemerintah No. 57, 2021) ${ }^{[1]}$. Pada proses pelaksanaan pendidikan ini diharapkan mengacu kepada peraturan perundangundangan terbaru yang senantiasa di perbaharui oleh Pemerintah Republik Indonesia seperti pada standar nasional pendidikan ini yang terakhir diperbaharui pada tanggal 31 Maret 2021. Selain menyesuaikan dengan peraturan terbaru, pelaksanaan pendidikan juga tidak bisa dipisahkan dari kearifan lokal daerah setempat. Seperti dalam penelitian Frentika dan Rizki (2020) ${ }^{[2]}$ yang meneliti tentang adanya hubungan pembelajaran matematika dalam permainan rakyat Kabuapten Sumbawa Barat (KSB) yaitu permainan Barapan Kebo dan Sampo Ayam. Seperti yang disampaikan oleh Abi (2016) ${ }^{[3]}$ bahwa dunia nyata dapat dibawa ke dalam proses pembelajaran peserta didik dengan mengangkat kearifan lokal daerah setempat. Selain itu, hasil penelitian yang telah dilakukan sebelumnya, kemudian dirubah sebagai materi pada bahan ajar yang digunakan dalam proses pembelajaran merupakan hal yang patut untuk dilakukan, seperti yang telah dilakukan dalam penelitian
Sahratullah, dkk (2017) ${ }^{[4]}$ yang selanjutnya dijadikan materi pada petunjuk praktikum berbasis guided inquiry pada penelitian Sahratullah dan Rahmawati (2020) $)^{[5]}$.

Petunjuk praktikum merupakan salah satu bahan ajar yang digunakan dalam proses pembelajaran. Tujuan digunakannya bahan ajar adalah untuk memudahkan peserta didik dalam melakukan kegiatan praktikum sehingga mempercepat proses pemahaman mereeka terhadap suatu materi. Sebelum bahan ajar digunanakan oleh peserta didik, bahan ajar tersebut harus dinyatakan layak dengan mengikuti berbagai tahapan, salah satunya adalah tahapan pengembangan. Ada beberapa beberapa tahapan pengembangan, jika menggunakan model pengembangan menurut Thiagarajan, dkk $(1974)^{[6]}$ model pengembangan 4D terdiri dari tahapan Pendefinisian (Define), thapan Perancangan (Design), tahapan Pengembangan (Develop), dan tahapan Penyebaran (Disseminate). Beberapa penelitian yang melakukan pengembangan bahan ajar diantaranya adalah Purnamasari (2012) $)^{[7]}$, Khasanah (2016) ${ }^{[8]}$, Dew (2019) $)^{[9]}$, Krisnawati (2018) ${ }^{[10]}$, Aryanti $(2019)^{[11]}$ serta penelitian Magdalena, dkk $(2020)^{[12]}$ dan masih banyak lagi penelitian pengembangan serupa lainnya.

Penelitian pengembangan terhadap bahan ajar yang telah dilakukan tersebut pada 
akhirnya akan menghasilkan sebuah produk berupa buku petunjuk praktikum yang akan digunakan oleh peserta didik SMA di KSB. Oleh karena itu perlu dilakukan langkah perlindungan terhadap karya yang telah dihasilkan tersebut. Seperti yang dinyatakan oleh Novita $(2020)^{[13]}$ bahwa perlindungan merek dapat menjamin adanya perlindungan hukum, sehingga memberikan ketenangan pengguna saat menggunakan merek tersebut. Karena seperti yang dijelaskan dalam Buku Hak Kekayaan Intelektual dan Tantangan Implementasinya di Perguruan Tinggi (Setyowati, dkk 2005) ${ }^{[14]}$ memaparkan bahwa pelaksanaan HKI di Indonesia masih kurang, yang dapat dipengaruhi oleh beberapa faktor salah satu diantaranya adalah kurangnya pemahaman masyarakat tentang sistem HKI. Potensi dari Implementasi Tridharma Perguruan Tinggi diharapkan mampu menghasilkan karya intelektual yang berdaya saing. Nurhayati (2007) ${ }^{[15]}$ pada penelitiannya telah menyatakan bahwa pada Universitas Terbuka (UT) tahun 2006 telah membentuk suatu Tim Pengelolaan dan Pengurusan Pengajuan HKI-UT yang mempunyai rincian tugas untuk megidentifikasi produk dan proses di UT yang perlu dilindungi hak ciptanya, melakukan pengurusan pengajuan HKI dan lainnya. Hal tersebut menunjukkan komitmen yang tinggi terhadap tujuan perlindungan produk dan proses, potensi serta implementasi dari Tridharma Perguruan Tinggi masing-masing. Adanya kegiatan seperti Workshop Pengenalan HKI dan Prosedur Pendaftarannya yang dilakukan oleh Universitas Negeri Yogyakarta (UNY) yang dilaksanakan pada tanggal 26 Januari 2018 (Berita UNY, 2018) ${ }^{[16]}$. Kegiatan Seminar Nasional Kekayaan Intelektual, Peran Kekayaan Intelektual dalam Membangun Ekonomi Negara yang dilaksanakan di Universitas Janabadra, Yogyakarta pada tanggal 10 Juli 2019. Pada kegiatan tersebut Direktur Jenderal Kekayaan Intelektual (Dirjen KI) menyatakan masih rendahnya permohonan KI karena kurangnya kesadaran masyarakat untuk melindungi hak kekayaan intelektualnya (DAW, 2019) ${ }^{[17]}$. Selain itu Direktorat Jenderal Kekayaan Intelektual
(DJKI) pada tanggal 12 Oktober 2019 telah melakukan penandatangan nota kesepahaman dengan Universitas Pamulang. Pada kegiatan tersebut Dirjen KI menghimbau mahasiswa serta dosen (SDM) untuk mendaftarkan KI nya sebagai salah satu upaya mendukung dalam memajukan Negara Indonesia (KAD, 2019) ${ }^{[18]}$. Pemerintah Daerah KSB juga telah melakukan kegiatan pemantauan dan pengawasan kekayaan intelektual serta penandatangan perjanjian kerjasama dengan Kantor Wilayah Hukum dan HAM NTB pada tanggal 7 April 2021 (prokopim, 2021) ${ }^{[19]}$. Sebagai dukungan terhadap KI, Kementerian Riset dan Teknologi melalui Deputi Bidang Penguatan Riset dan Pengembangan telah mengeluarkan Panduan Pengususl Insentif HKI Produktif, dengan tujuan untuk memberikan stimulus kepada penggiatn KI dan peneliti agar terus menghasilkan karya yang komersial dan mendukung pertumbuhan ekonomi Indonesia (Ristek-Brin, 2020) ${ }^{[20]}$.

Penjelasan tersebut menjadi pertimbangan bagi peneliti untuk melakukan pengusulan HKI untuk produk dari kegiatan penelitian yang dilakukan, yaitu berupa Buku Petunjuk Praktikum Bioteknologi berbasis guided inquiry untuk peserta didik SMA serta Buku Petunjuk Praktikum Bioteknologi berbasis guided inquiry sebagai pegangan Guru SMA.

\section{METODE PENELITIAN}

Metode penelitian pengembangan ini menggunakan model pengembangan 4D dari Thiagarajan, dkk (1974) ${ }^{[6]}$. Adapun rincian masing-masing tahapan yang telah dilakukan adalah sebagai berikut: (1) pada tahap pertama, proses yang dilakukan adalah mendefinisikan serta menetapkan apa saja syarat dalam pembelajaran. (2) selanjutnya merancang silabus, RPP, dan petunjuk praktikum bioteknologi berbasis guided inquiry yang merupakan perangkat pembelajaran utama. Selain perangkat pembelajaran tersebut instrumen penelitian juga perlu dirancang seperti soal pre-tes dan post-tes, angket validasi konstruk dan isi petunjuk praktikum bioteknologi berbasis guided inquiry oleh validator dan angket 
validasi keterbacaan petunjuk praktikum bioteknologi berbasis guided inquiry oleh guru dan peserta didik. (3) pada proses pengembangan dimulai dengan melakukan validasi ahli pertama oleh dua validator. Jika sudah dianggap sesuai dan layak (melalui proses revisi masukan dari validator) selanjutnya dilakukan uji keterbacaan petunjuk praktikum oleh peserta didik dengan menggunakan dua sekolah yang berbeda. (4) tahap terakhir yang dilakukan adalah revisi akhir dari masukan saat uji keterbacaan, di validasi lagi oleh ahli, jika dinyatakan layak maka dilakukan penyebaran dan penerapan perangkat pembelajaran dan instrumen penelitian.

Penelitian ini merupakan penelitian lanjutan dari penelitian yang sebelumnya berfokus pada tahapan 3D (Develop) yaitu mengembangkan petunjuk praktikum berbasis guided inquiry. Selain proses pengembangan petunjuk praktikum, pada tahap ini juga dilakukan proses validasi ahli, uji keterbacaan peunjuk praktikum oleh guru dan peserta didik. Kegiatan pengembangan khususnya pengembangan petunjuk praktikum tersebut telah dilakukan oleh Sahratullah dan Rahmawati (2020) ${ }^{[5]}$ yang menunjukkan rerata skor penilaian sebesar 3,35 serta nilai hasil validasi ahli sebesar $88,75 \%$ dengan kriteria sangat baik. Selain itu penelitian tersebut juga menunjukkkan hasil uji keterbacaan oleh peserta didik kelas XII IPA SMAN 1 Jereweh. Kegiatan uji keterbacaan juga telah dilakukan oleh Rahmawati dan Sahratullah (2020) ${ }^{[21]}$ pada peserta didik kelas XII SMAN 2 Taliwang dengan nilai rerata skor sebesar 68,61 dan persentase sebesar $71,47 \%$ dengan kriteria mudah.

Berdasarkan pada tahapan metode pengembangan Thiagarajan, dkk $(1974)^{[6]}$ perlu dilakukan lagi validasi ahli terhadap petunjuk praktikum berbasis guided inquiry untuk dinilai kevalidan, keterbacaan, serta kelayakannya setelah proses revisi. Adapun gambaran tahapan dari alur penelitian yang telah dilakukan pada penelitian ini berdasarkan metode pengembangan adalah sebagai berikut.

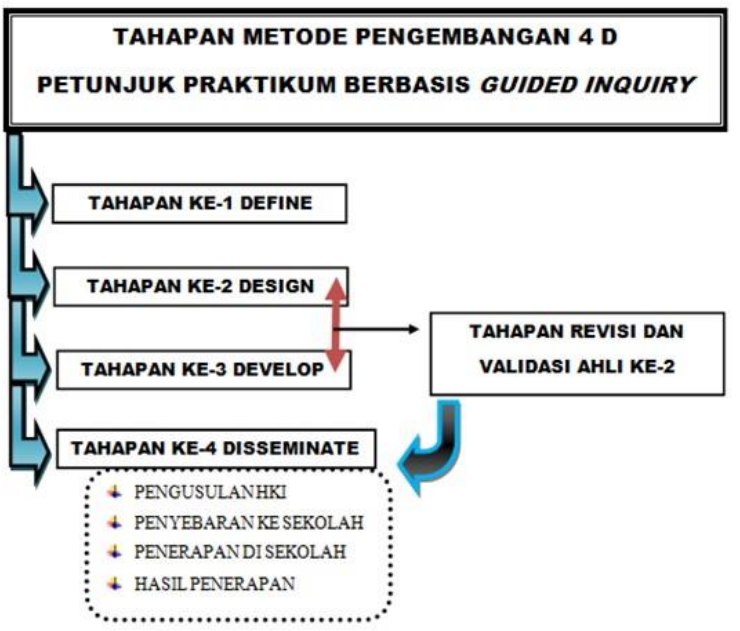

Gambar 1. Tahapan Pengembangan Metode 4D (Sumber: Dokumen pribadi)

Hasil validasi ahli ke-2 oleh validator ahli dari Dosen Program Studi Pendidikan Biologi Universitas Cordova (Fitri Rahmawati, M. Pd dan Hilda Ernani, M.Pd) yang menilai konstruk dan isi petunjuk praktikum bioteknologi berbasis guided inquiry yang telah direvisi. Adapun hasil validasi ditampilkan pada Tabel 3 yang telah melalui tahapan analisis. Tahapan analisis sendiri terdiri dari dua tahap, yaitu (1) tahap analisis tingkat kevalidan, menggunakan rumus rerata skor (Vendiktama, dkk $(2018)^{[22]}$ ) dengan cara menjumlahkan seluruh skor yang telah diberikan oleh kedua validator kemudian, dirata-ratakan. Nilai akhir tersebut nantinya akan dicocokkan dengan kriteria kevalidan pada Tabel 1 sebagai berikut.

Tabel 1. Kriteria kevalidan petunjuk praktikum berbasis guided inquiry

\begin{tabular}{|c|c|}
\hline Rerata skor & Kriteria penilaian \\
\hline $3,50-4,00$ & Sangat valid \\
\hline $2,50-3,49$ & Valid \\
\hline $1,50-2,49$ & Tidak valid \\
\hline $1,00-1,49$ & Sangat tidak valid \\
\hline
\end{tabular}

Tahapan analisis selanjutnya adalah (2) melakukan analisis terhadap konstruk dan isi, dengan cara mencari nilai persentase dengan menggunakan rumus dari Fajarianingtyas dan Hidayat (2019) ${ }^{[23]}$ seperti berikut.

\footnotetext{
Persentase $(\%)=\frac{\text { jumlah }(\text { jawaban } \mathrm{x} \text { bobot setiap pilihan })}{\mathrm{N} \times \text { bobot tertinggi }} \times 100 \%$
} 
Apabila nilai persentasenya sudah ditemukan, maka langkah selanjutnya adalah mencocokkan nilai tersebut dengan kriteria yang telah ditetapan oleh Fajarianingtyas dan Hidayat (2019) ${ }^{[23]}$ pada Tabel 2 di bawah ini.

Tabel 2. Kriteria hasil validasi konstruk dan isi petunjuk praktikum berbasis guided inquiry

\begin{tabular}{ccc}
\hline $\begin{array}{c}\text { Tingkat } \\
\text { pencapaian }(\boldsymbol{\%})\end{array}$ & Kriteria & Keterangan \\
\hline$>80$ & Sangat baik & Tidak perlu direvisi \\
\hline $70-79$ & Baik & Tidak perlu direvisi \\
\hline $60-69$ & Cukup & Direvisi \\
\hline $50-59$ & Kurang & Direvisi \\
\hline$<50$ & Sangat kurang & Direvisi \\
\hline
\end{tabular}

Sebelum pelaksanaan kegiatan penelitian ini, peneliti memang masih kekurangan informasi tentang segala sesuatu yang berhubungan dengan perlindungan hak cipta. Tetapi saat ini peneliti sudah paham alur, persyaratan, dan cara mengajukan permohonan HKI setelah mulai mengumpulkan informasi dan melakukan proses pengusulan permohonan HKI melalui sentra KI yang ada di Universitas Teknologi Sumbawa.

\section{HASIL PENELITIAN DAN PEMBAHASAN}

Seperti yang sudah dijelaskan sebelumnya bahwa telah dilakukan validasi ahli ke-2 setelah petunjuk praktikum bioteknologi berbasis guided inquiry ini direvisi. Aspek-aspek yang dinilai pada kegiatan validasi diantaranya adalah tentang aspek konstruk/ desain petunjuk praktikum (terdiri dari (1) Kejelasan tujuan penggunaan petunjuk praktikum, (2) Kejelasan keterangan petunjuk pengisian petunjuk praktikum, (3) Kejelasan tampilan kolom isian tabel penilaian, dan (4) Kejelasan urutan aspek yang dinilai). Aspek berikutnya adalah isi/ materi petunjuk praktikum (terdiri dari (1) Kesesuaian judul dengan tujuan pengisian petunjuk praktikum, (2) Ketepatan pertanyaan yang digunakan dalam petunjuk praktikum, (3) Kejelasan tahapan cara pengisian petunjuk praktikum, (4) Kejelasan kalimat yang digunakan dalam petunjuk praktikum, (5) Keefektifaan redaksi kalimat yang ada dalam petunjuk praktikum, dan (6) Kalimat pada petunjuk praktikum tidak menimbulkan penafsiran ganda atau salah pengertian). Adapun hasil validasi ahli ke-2 yang telah dilakukan akan ditampilkan pada Tabel 3 di bawah ini.

Tabel 3. Hasil validasi ke-2 oleh Validator I dan II

\begin{tabular}{|c|c|c|}
\hline \multirow{2}{*}{ Aspek yang dinilai } & \multicolumn{2}{|c|}{ Skor } \\
\hline & Validator I & Validator II \\
\hline \multicolumn{3}{|l|}{$\begin{array}{l}\text { Konstruk/Desain Petunjuk } \\
\text { Praktikum }\end{array}$} \\
\hline $\begin{array}{l}\text { 1. Kejelasan tujuan penggunaan } \\
\text { petunjuk praktikum }\end{array}$ & 3 & 3 \\
\hline $\begin{array}{l}\text { 2. Kejelasan keterangan petunjuk } \\
\text { pengisian petunjuk praktikum }\end{array}$ & 3 & 3 \\
\hline $\begin{array}{l}\text { 3. Kejelasan tampilan kolom } \\
\text { isian tabel penilaian }\end{array}$ & 3 & 3 \\
\hline $\begin{array}{l}\text { 4. Kejelasan urutan aspek yang } \\
\text { dinilai }\end{array}$ & 3 & 3 \\
\hline \multicolumn{3}{|l|}{ Isi/Materi Petunjuk Praktikum } \\
\hline $\begin{array}{l}\text { 1. Kesesuaian judul dengan } \\
\text { tujuan pengisian petunjuk } \\
\text { praktikum }\end{array}$ & 3 & 3 \\
\hline $\begin{array}{l}\text { 2. Ketepatan pertanyaan yang } \\
\text { digunakan dalam petunjuk } \\
\text { praktikum }\end{array}$ & 3 & 3 \\
\hline $\begin{array}{l}\text { 3. Kejelasan tahapan cara } \\
\text { pengisian petunjuk praktikum }\end{array}$ & 3 & 3 \\
\hline $\begin{array}{ll}\text { 4. } & \text { Kejelasan kalimat yang } \\
\text { digunakan dalam instrumen }\end{array}$ & 3 & 3 \\
\hline $\begin{array}{l}\text { 5. Keefektifaan redaksi kalimat } \\
\text { yang ada dalam petunjuk } \\
\text { praktikum }\end{array}$ & 3 & 3 \\
\hline $\begin{array}{l}\text { 6. Kalimat pada petunjuk } \\
\text { praktikum tidak menimbulkan } \\
\text { penafsiran ganda atau salah } \\
\text { pengertian }\end{array}$ & 3 & 3 \\
\hline Rerata skor & 3 & 3 \\
\hline Kriteria kevalidan rerata skor & \multicolumn{2}{|c|}{ Valid } \\
\hline Persentase skor & $75 \%$ & $75 \%$ \\
\hline Persentase Rerata skor & \multicolumn{2}{|c|}{$75 \%$} \\
\hline Kriteria Persentase rerata skor & \multicolumn{2}{|c|}{ Baik } \\
\hline Keterangan & \multicolumn{2}{|c|}{ Tidak perlu direvisi } \\
\hline
\end{tabular}

Sumber: dokumen pribadi

Hasil validasi tahap kedua ini mendapatkan nilai rerata skor $\mathbf{3}$ dengan kriteria kevalidan rerata skor adalah Valid apabila dicocokkan dengan kriteria kevalidan oleh Vendiktama, dkk (2018) ${ }^{[22]}$. Untuk nilai persentase skornya diperoleh nilai sebesar 75\% dengan nilai rata-rata yang sama sebesar 75\% juga. Jika dicocokkan dengan kriteria Fajarianingtyas dan Hidayat (2019) ${ }^{[23]}$ maka diperoleh kriteria rerata skor adalah Baik dengan keterangan Tidak Perlu Direvisi.

Selanjutnya akan ditampilkan beberapa tampilan dari karakteritik Petunjuk Praktikum Berbasis Guided Inquiry sebagai 
pegangan guru SMA (yang terdiri dari halaman cover, daftar isi, petunjuk pelaksanaan praktikum, KD dan indikator pencapaian kompetensi, peta konsep, Lembar Kerja Praktikum, daftar pustaka, lampiran 1 Hasil Pengamatan, lembar penilaian organoleptik tape singkong, lembar kriteria kesukaan panelis tape singkong, serta Lembar dan Rubrik Penilaian Laporan Praktikum) dan karakteritik Petunjuk Praktikum Berbasis Guided Inquiry untuk peserta didik SMA (yang terdiri dari halaman cover, daftar isi, petunjuk pelaksanaan praktikum, KD dan indikator pencapaian kompetensi, peta konsep, Lembar Kerja Praktikum, daftar pustaka, lampiran 1 Hasil Pengamatan, lembar penilaian organoleptik tape singkong, lembar kriteria kesukaan panelis tape singkong, dan format pembuatan laporan praktikum).

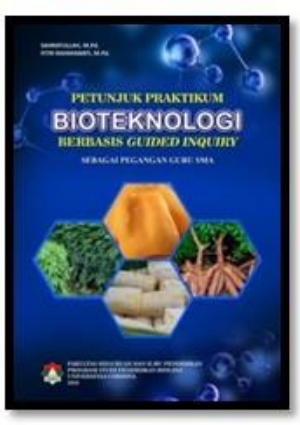

(a)

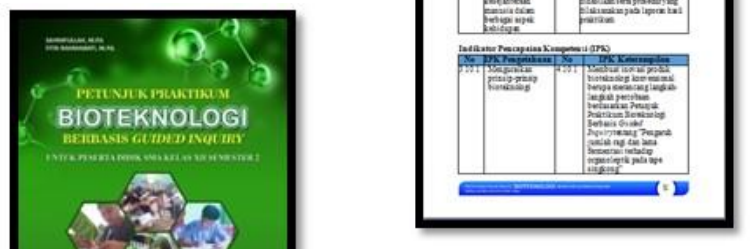

(a)

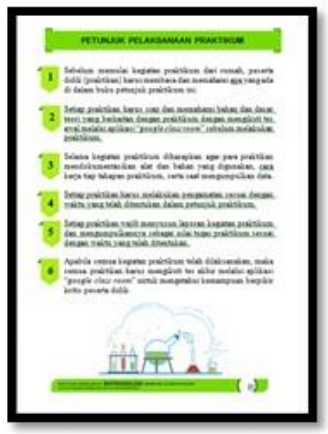

(b)
Gambar 4. Petunjuk pelaksanaan praktikum bioteknologi berbasis guided inquiry (a) sebagai pegangan guru, dan (b) untuk peserta didik SMA, Sumber: dokumen pribadi

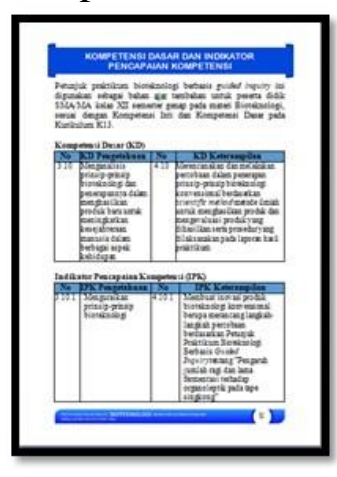

Gambar 5. KD dan IPK pada petunjuk praktikum bioteknologi berbasis guided inquiry (a) sebagai pegangan guru, dan (b) untuk peserta didik SMA, Sumber: dokumen pribadi

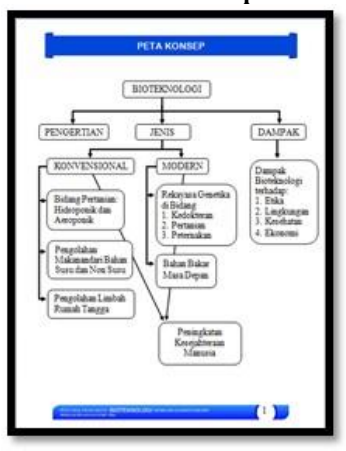

(a)

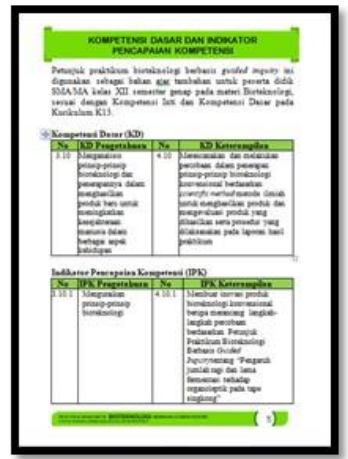

(b)
Gambar 2. Cover pada petunjuk praktikum bioteknologi berbasis guided inquiry (a) sebagai pegangan guru, dan (b) untuk peserta didik SMA, Sumber: dokumen pribadi

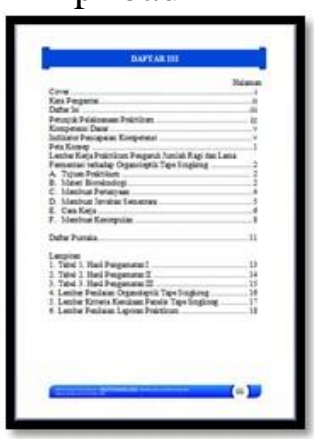

(a)

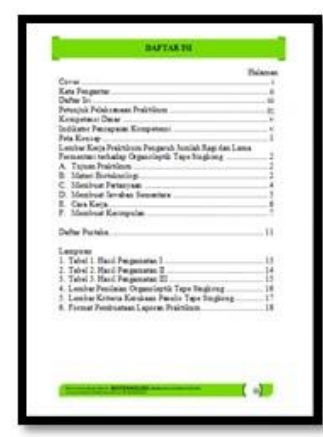

(b)
Gambar 3. Daftar isi petunjuk praktikum bioteknologi berbasis guided inquiry (a) sebagai pegangan guru, dan (b) untuk peserta didik SMA, Sumber: dokumen pribadi

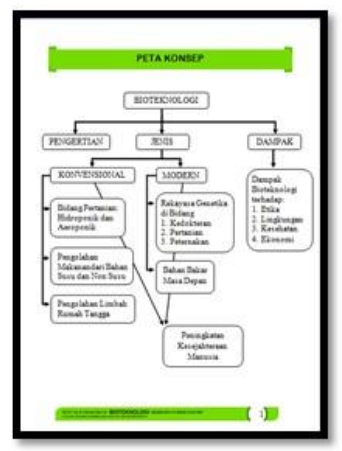

(b)
Gambar 6. Peta Konsep pada petunjuk praktikum bioteknologi berbasis guided inquiry (a) sebagai pegangan guru, dan (b) untuk peserta didik SMA, Sumber: dokumen pribadi 


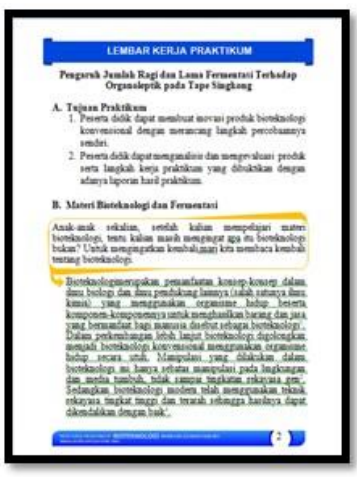

(a)

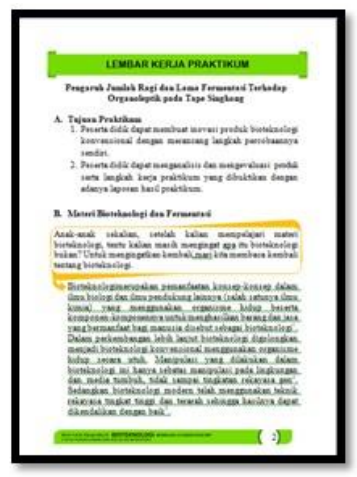

(b)

Gambar 7. Lembar Kerja Praktikum pada buku petunjuk praktikum bioteknologi berbasis guided inquiry (a) sebagai pegangan guru, dan (b) untuk peserta didik SMA, Sumber: dokumen pribadi

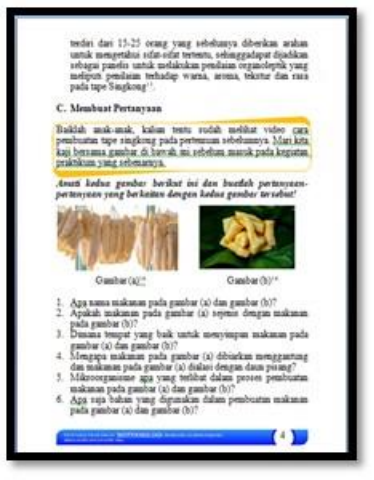

(a)

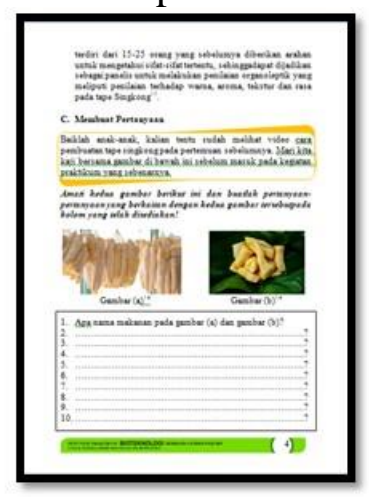

(b)

Gambar 8. Perbedaan bagian cara membuat pertanyaan pada Lembar Kerja Praktikum (a) sebagai pegangan guru, dan (b) untuk peserta didik SMA, Sumber: dokumen pribadi

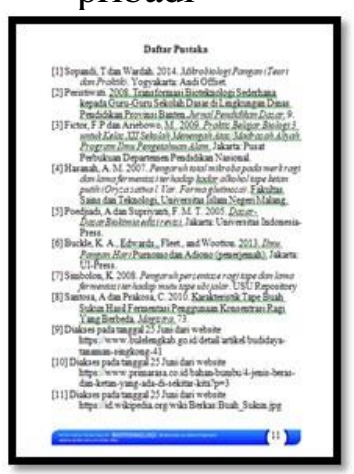

(a)

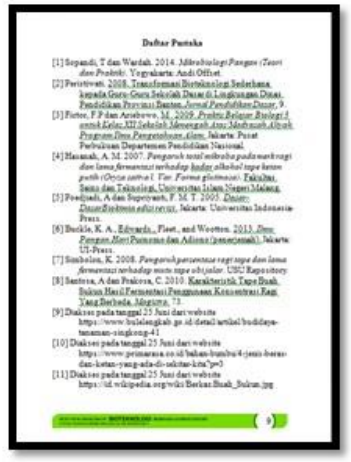

(b)

Gambar 9. Daftar Pustaka pada petunjuk praktikum bioteknologi berbasis guided inquiry (a) sebagai pegangan guru, dan (b) untuk peserta didik SMA, Sumber: dokumen pribadi
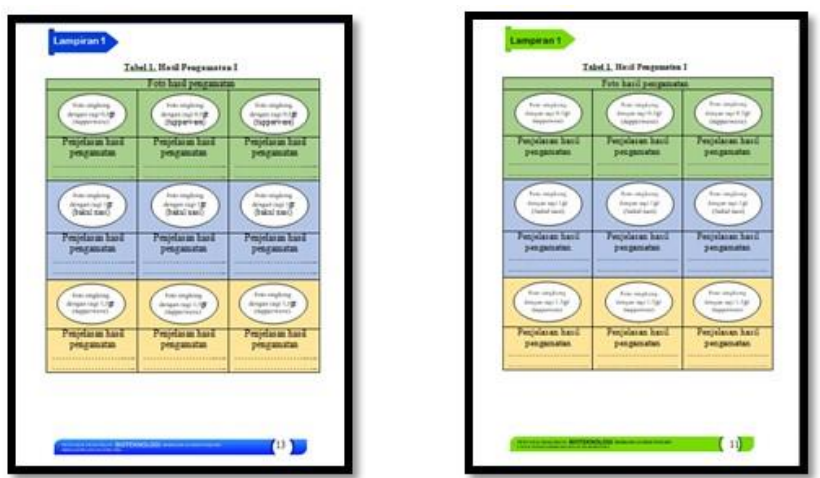

(a)

(b)

Gambar 10. Lampiran 1 Hasil Pengamatan pada Praktikum bioteknologi berbasis guided inquiry (a) sebagai pegangan guru, dan (b) untuk peserta didik SMA. Sumber: dokumen pribadi

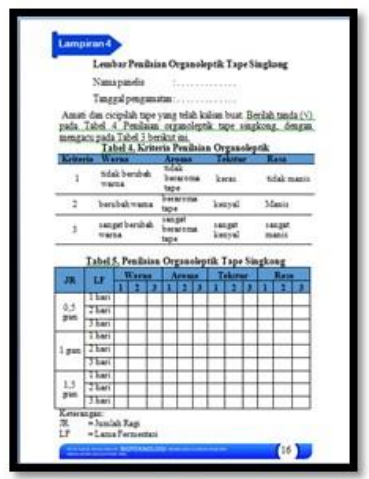

(a)

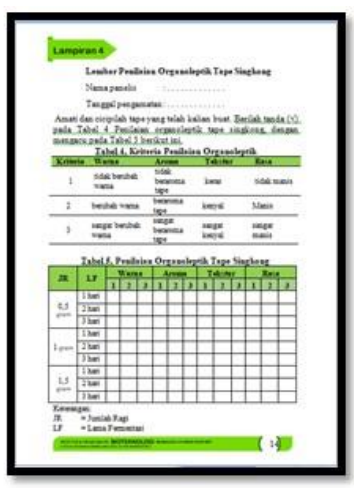

(b)

Gambar 11. Lembar penilaian organoleptik tape singkong pada Praktikum bioteknologi berbasis guided inquiry (a) sebagai pegangan guru, dan (b) untuk peserta didik SMA, Sumber: dokumen pribadi

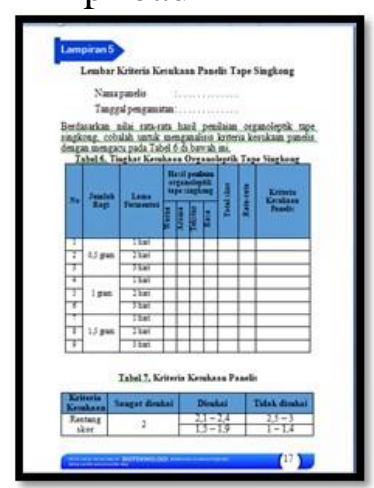

(a)

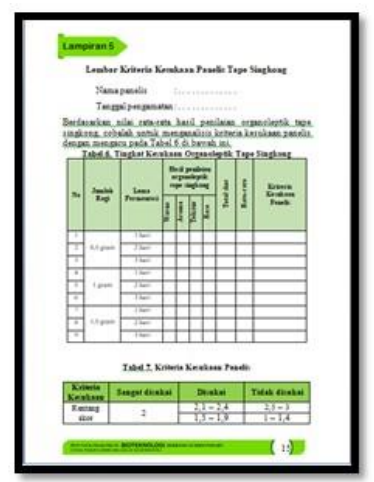

(b)

Gambar 12. Lembar kriteria kesukaan panelis tape singkong, Praktikum bioteknologi berbasis guided inquiry (a) sebagai pegangan guru, dan (b) untuk peserta didik SMA, Sumber: dokumen pribadi 


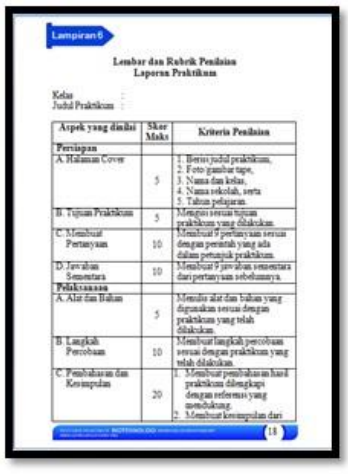

(a)

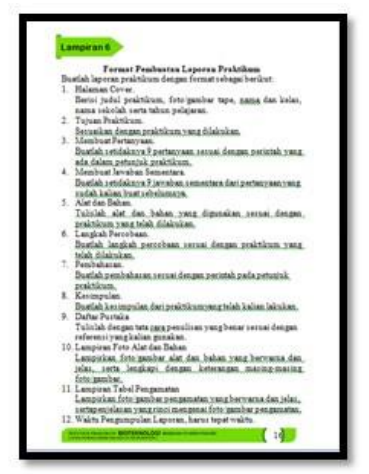

(b)
Gambar 13. (a) Lembar dan Rubrik Penilaian Laporan Praktikum sebagai pegangan guru, dan (b) Format pembuatan laporan untuk peserta didik SMA, Sumber: dokumen pribadi

Adapun hasil dari pengusulan HKI adalah adanya sertifikat yang membuktikan bahwa ajuan kita telah diterima. Pada penelitian ini akan ditampilkan sertifikat HKI yang diperoleh untuk Buku Petunjuk Praktikum Bioteknologi Berbasis Guided Inquiry sebagai Pegangan Guru SMA (Gambar 14 a) dan Buku Petunjuk Praktikum Bioteknologi Berbasis Guided Inquiry untuk Peserta Didik SMA Kelas XII Semester 2 (Gambar 14 b) dapat dilihat pada gambar dibawah ini.

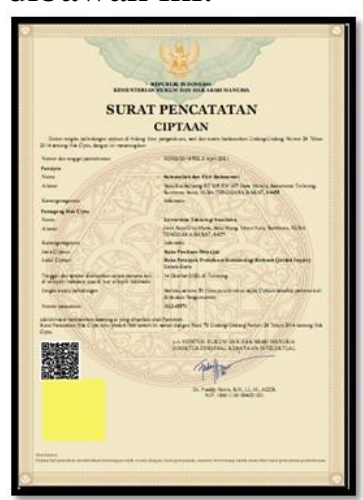

(a)

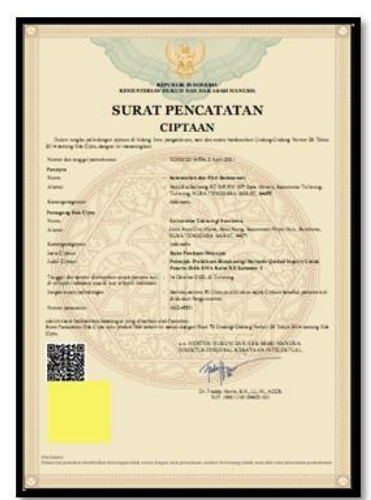

(b)
Gambar 14. (a) Sertifikat HKI untuk petunjuk praktikum bioteknologi berbasis guided inquiry sebagai pegangan guru, dan (b) Sertifikat HKI untuk petunjuk praktikum bioteknologi berbasis guided inquiry peserta didik SMA, Sumber: dokumen pribadi

\section{KESIMPULAN}

Kesimpulan penelitian berdasarkan hasil penelitian dan pembahasan adalah petunjuk praktikum bioteknologi berbasis guided inquiry hasil validasi ahli ke-2 dinyatakan "valid" dengan nilai rerata skor $\mathbf{3}$ dan persentase sebesar $\mathbf{7 5 \%}$ dan kriteria "Baik" serta keterangan "Tidak Peril Direvisi". Petunjuk praktikum bioteknologi berbasis guided inquiry ini juga telah mendapatkan sertifikat HKI dan dapat diimplementasikan dalam proses pembelajaran untuk peserta didik SMA di Kabupaten Sumbawa Barat.

\section{SARAN}

Ada beberapa saran yang ingin disampaikan peneliti: (1) semoga dengan adanya penelitian ini yang telah menghasilkan pengembangan berupa bahan ajar (petunjuk praktikum) bisa menggugah kesadaran dan minat peneliti lain khususnya yang bergerak di dunia pendidikan, untuk terus melakukan pengembangan baik itu berupa bahan ajar, hingga media pembelajaran yang akan digunakan dalam proses pembelajaran. (2) perlu diperhatikan dengan seksama, bahwa pengajuan dan permohonan penerbitan HKI itu tidak sulit, tetapi sudah dimudahkan dengan cara pengurusan online. Sehingga diharapkan para peneliti, pemerhati pendidikan dan masyarakat secara umumnya untuk mau menjaga hak dari kekayaan intelektual yang kita miliki. Saat kita membuat atau menciptakan suatu karya butuh proses, waktu dan tenaga, tetapi kita juga harus melindungi hak dari karya yang telah susah payah kita hasilkan. Jadi mari daftarkan, dan mulailah membuat pengajuan untuk setiap karya yang telah kita hasilkan, yang dalam proses pembuatan, dan yang rencananya akan kita buat.

\section{UCAPAN TERIMA KASIH}

Penelitian ini dibiayai oleh Direktorat Riset dan Pengabdian Masyarakat, Deputi Bidang Penguatan Riset dan Pengembangan, Kementerian Riset dan Teknologi/ Badan Riset dan Inovasi Nasional sesuai dengan Kontrak Penelitian Tahun Anggaran 2021. 
Terima kasih kami sampaikan kepada semua pihak yang membantu penelitian yang kami laksanakan diantaranya adalah Kementerian Riset dan Teknologi/ Badan Riset dan Inovasi Nasional, Program Studi Pendidikan Biologi, Fakultas Keguruan dan Ilmu Pendidikan Universitas Cordova, LRP2M Universitas Cordova, Bappeda Litbang Kabupaten Sumbawa Barat, SMA Negeri 1 Jereweh, SMAN 2 Taliwang, serta semua pihak-pihak yang terlibat dalam penelitian ini.

\section{DAFTAR PUSTAKA}

[1] Peraturan Pemerintah Nomor 57 Tahun 2021. 2021. Standar Nasional Pendidikan. Kementerian Hukum dan Hak Asasi Manusia. Lembaran Negara Republik Indonesia Tahun 2021 Nomor 87. Diakses pada tanggal 20 Oktober 2021 dari website http://pjmuniramalang.ac.id

[2] Frentika, D., dan Rizki, H.T.N. 2020. Geometri dan pengukuran dalam permainan rakyat Kabupaten Sumbawa Barat. Jurnal pendidikan MIPA, 10 (2), 86-93. https://doi.org/10.37630/jpm. v10i2.346

[3] Abi, A.M. 2016. Integrasi etnomatematika dalam kurikulum matematika sekolah. Jurnal Pendidikan Matematika Indonesia, 1 (1), 1-6.

http://dx.doi.org/10.26737/jp mi.v1il.75

[4] Sahratullah., Jekti, D.S.D., dan Zulkifli, L. 2017. Pengaruh Konsentrasi Ragi dan Lama Fermentasi terhadap Kadar Air, Glukosa dan Organoleptik pada Tape Singkong. Jurnal Biologi Tropis. Volume 17 Nomor 1 e-ISSN: 2549-7863.
Sahratullah dan Rahmawati, F. 2020. Pengembangan petunjuk praktikum berbasis guided inquiry untuk peserta didik SMA di Kabupaten Sumbawa Barat. Jurnal Ilmiah Mandala Education (JIME), 6 (2), 474-481.

[6] Thiagarajan, S., Semmel, D.S., dan Semmel, M.I. 1974. Instruction Development for Training Teacher of Exceptional Children: A Sourcebook. Indiana University Bloomington. Diunduh dari http://file.eric.ed.gov/fulltext/ED090725.pdf pada tanggal 17 Agustus 2019.

[7] Purnamasari, S. 2012. Pengembangan Petunjuk Praktikum Kimia SMA pada Pokok Bahasan Stoikiometri. Skripsi diterbitkan. Semarang: UPI.

[8] Khasanah, U. 2016. Pengembangan Bahan Ajar dalam Rangka Peningkatan Pemahaman Siswa terhadap Materi Peran Pers dalam Menyebabkan Paham Kebangsaan pada Masa Pergerakan Nasional di MA Padureso Tahun Pelajaran 2015/2016. Skripsi. Jurusan Sejarah, Fakultas Ilmu Sosial, Universitas Negeri Semarang: Semarang.

[9] Dew, V.J. 2019. Pengembangan Bahan Ajar dengan Pendekatan Kontekstual Berbasis Project Based Learning pada Materi Bioteknologi untuk SMA Kelas XII. Skripsi. Program Studi Pendidikan Biologi, Jurusan Pendidikan Matematika dan Ilmu Pengetahuan Alam, Fakultas Keguruan dan Ilmu Pendidikan, Universitas Sanata Dharma: Yogyakarta. 
[10] Krisnawati,

R.D.

2018.

Pengembangan Instrumen

Penilaian Berbasis HOTS pada Kompetensi Dasar Menganalisis Perkiraan untuk Menyusun Laporan

Keuangan Kelas X Akutansi SMK. Skripsi. Program Studi Pendidikan Ekonomi, Bidang Keahlian Khusus Pendidikan Akutansi, Jurusan Pendidikan Ilmu Pengetahuuan Sosial, Fakultas Kependidikan dan Ilmu Pendidikan, Universitas Sanata Dharma: Yogyakarta.

[11] Aryanti, S. 2019. Pengembangan Modul Berbasis Model Guided Inquiry untuk Mengembangkan Critical Thinking Skill pada Materi Ekologi Kelas X di SMA. Skripsi. Program Studi Pendidikan Biologi Fakultas Keguruan dan Ilmu Pendidikan Universitas Muhammadiyah Palembang: Palembang.

[12] Magdalena, I., Prabandani, R.O., Rini, E.S., Fitriani, M.A., dan Putri, A.A. 2020. Analisis Pengembangan Bahan Ajar. Nusantara: Jurnal Pendidikan dan Ilmu Sosial, 2 (2), Juli 2020; 170-187. Diakses dari website https://ejournal.stitpn.ac.id/in dex.php/nusantara

[13] Novita, D. 2020. Hak Kekayaan Intelektual bagi Pemegang Hak Merek Suatu Karya Intelektual. Jurnal Jendela Humum, 7 (1) Fakultas Hukum UNIJA.

[14] Setyowati, K., Lubis, E., Anggraeni, E., dan Wibowo, M.H. 2005.

Hak Kekayaan Intelektual dan Tantangan Implementasinya di Perguruan Tinggi. Kantor HKI-IPB: Bogor.
[15] Nurhayati, R. 2007. Hak Kekayaan Intelektual pada Pendidikan Tinggi Jarak Jauh. Jurnal Pendidikan Terbuka dan Jarak Jauh, 8 (1), Maret 2007, 24-39.

[16] Berita UNY. 2018. Pentingnya Hak Kekayaan Intelektual bagi Sivitas Akademika UNY. Diakses pada website https://www.uny.ac.id/berita/ pentingnya-hak-kekayaanintelektual-bagi-sivitasakademika-uny.

[17] DAW. 2019. Dirjen KI ajak Peneliti Perguruan Tinggi Lindungi Kekayaan Intelektual Hasil Penelitian. Diakses pada website https://dgip.go.id/artikel/detai 1-artikel/dirjen-ki-ajakpeneliti-perguruan-tinggilindungi-kekayaanintelektual-hasilpenelitian?kategori=Berita\% 20Resmi\%20Desain\%20Indu stri

[18] KAD. 2019. Dirjen KI ajak dosen dan mahasiswa Universitas Pamulang hasilkan penelitian yang memiliki nilai ekonomi. Diakses pada website https://dgip.go.id/artikel/detai 1-artikel/dirjen-ki-ajak-dosendan-mahasiswa-universitaspamulang-hasilkanpenelitian-yang-memilikinilaiekonomi?kategori=Berita $\% 2$ 0Resmi\%20Desain\%20Indus tri

[19] Prokopim. 2021. Lindungi Kekayaan Intelektual, PEMDA KSB Kerjasama dengan KANWIL KEMENHUMKAM NTB. Diakses pada tanggal 20 Oktober 2021 dari website https://sumbawabaratkab.go.i d/lindungi-kekayaanintelektual-pemda-ksb- 
kerjasama-dengan-kanwil-

kemenkumham-ntb/

[20] Ristek-Brin. 2020. Panduan Pengusul Insentif HKI Produktif.

Deputi Bidang Penguatan

Riset dan Pengembangan.

Kementerian Riset dan

Teknologi/ Badan Riset dan Inovasi Nasional.

[21] Rahmawati, F. dan Sahratullah. 2020. Validitas petunjuk praktikum bioteknologi berbasis guided inquiry untuk peserta didik SMA di Kabupaten Sumbawa Barat. Bioscientist : Jurnal Ilmiah Biologi. Volume 8 (2). E-ISSN 26544571 P-ISSN: 2338-5006. Diakses dari website http://ejournal.mandalanursa. org/index.php/JIME/index

[22] Vendiktama, P.R., Al-Muhdar, M.H.I. dan Suarsini, E. 2018. Pengembangan Modul Biologi Bermuatan Konsep $6 \mathrm{M}$ dan Etika Lingkungan Berbasis Model Project Based Learning (PjBL) untuk Siswa SMA. Jurnal Pendidikan. Volume 3 (2). Februari 2018. E-ISSN: 2502-471X. DOAJSHERPA/RoMEO-Google

Scholar-IPI.

[23] Fajarianingtyas, D.A., dan Hidayat, J.N. 2019. Validitas Buku Petunjuk Praktikum Biologi Dasar Berbasis Pemecahan Masalah untuk Mahasiswa Pendidikan IPA di Universitas Wiraraja. Lensa (Lentera Sains): Jurnal Pendidikan IPA. Volume 9 (2). November 2019. ISSN: 2301-5071. E-ISSN: 24067393. 